\title{
Changing Orientation of Japan's Official Development Assistance
}

- Characteristics and Challenges -

\author{
Ryokichi Hirono (Seikei University, Tokyo)
}

\section{Contents}

Introduction

1. Changing ODA Policy Orientation

1) Basic Philosophy and Principles: ODA Charters Revisited

2) Strategic Initiatives in response to Changing Global Issues

3) Programme and Sector Priorities consistent with Global Commitments

4) Dramatic Changes in Regional Focus

5) Changing Panorama of Country Choices: Tug of War between Global Preferences and Diplomatic Priorities

2. Implementation Dynamics

1) ODA Policy and Implementation Decision Machinery

2) Consultation with Partner Countries

3) Coordination among Major Bilateral Donors and Multilateral Development Institutions

4) Reorganization of Operational Modalities for Greater Impact

5) Monitoring and Evaluation (M\&E) for Better Planning and Programming

6) Transparency and Accountability for Greater Efficiency and Equity

3. Quo Vadis ? 


\section{Introduction}

Thanks to the enormous assistance by the Allied Powers and especially the United States as well as by the serious efforts of the government and all the other stakeholders at home, Japan was able to undertake various economic, social and political reforms that enabled a rapid economic reconstruction during the immediate postwar years 1945-50. Following the conclusion of the San Francisco Peace Treaty in 1951, Japan initiated a number of diplomatic moves, first fulfilling their commitment under the Peace Treaty obligations to making reparations payments, as scheduled, mainly to those countries of Asia and the Pacific where Japan had afflicted atrocities on the people during the World War II, and secondly joining the International Monetary Fund and the International Bank for Reconstruction and Development (World Bank) and various specialized agencies of the United Nations in order to gain access to financial and technical assistance regime of the international community ${ }^{1}$.

By 1952 Japan was able to stand on their own feet and lay all the foundations for a rapid economic development and embarked, though on a small scale, its development assistance in 1954 through its establishment of Asia Association and joined the United States, the United Kingdom and other former metropolitan countries in strengthening the Colombo Plan to extend its technical assistance to those developing countries of Asia and the Pacific. Also, learning from the experiences of the Colombo Plan participation, Japan established the Overseas Technical Cooperation Agency OTCA) and the Overseas Economic Cooperation Fund OECF) in 1961 and joined the rest of the OECD countries in providing official development assistance ODA) to support all those developing countries struggling to solve those burning issues under adverse economic,

1) Most outstanding examples of such international assistance in the postwar years were the enormous help given by UNICEF, the commodity aid under GARIO started in July, 1947 and EROA in August, 1948 during the Occupation period and the technical assistance of the United States started in 1952 for improving technology and productivity of Japanese manufacturing industries and public utilities under the U.S.-Japan Technical Assistance Agreement, as well as the World Bank loans started in January, 1953 among others to install Aichi Irrigation System, build Tokaido Turnpikes, and Tokaido Bullet Train System. Repayment of oth GARIO and EROA was completed as early as in January, 1962 and World Bank loans as late as in July, 1990. 
social and political conditions at home and overseas.

While it is true that behind the Japanese decision to join OECD as its full member in 1964 was the prevailing consensus among the United States and its allies to contain the communist infiltration into developing countries under the Cold War regime, Japan, having gone through hard struggles for survival and reconstruction in the immediate postwar years, was determined to assist those developing countries where over three billion people were still suffering from famine, malnutrition, poverty and an inadequate access to basic education and primary healthcare. It is also to be noted that by assisting developing countries of Asia and the Pacific in promoting economic development and social stability, Japan has benefited a great deal from a greater access on the one hand to their rapidly growing domestic market to expand Japanese manufactured exports, and on the other to industrial raw materials such as petroleum and minerals essential to running its own rapidly growing industry. During the years 1961- 2013, there have been enormous changes both in Japan and the rest of the world in terms of the per capita GNI, the economic structure of both developed and developing countries, the emergence of new players on the international trade, investment and financial markets and the nature and magnitude of global issues facing all the countries of the world. In order to meet those changing domestic and global challenges, Japan not only increased its ODA in volume, as shown in Table 1-1 \& 1-2 below, by leaps and bound in the 1960s till mid-90s, but also took many strategic initiatives. Its ODA, however, began to decline steadily with its peak year in 1997, reflecting the stagnation of its economy and deepening of its fiscal deficits at the central and local government levels, as well as the adverse impact of the Tohoku Great Earthquake and Tsunami hit on 11 March, 2011. Accordingly, Japanese ODA as percent of GDP also went down from a peak of 0.37 in 1980 to 0.18 in 2011. In the meantime its ODA policies and implementation machinery have undergone dramatic changes ever since 1961. It is the purpose of this paper to discuss those dramatic changes observed in Japanese ODA policies during the last sixty years or so in terms of strategic initiatives, programmes and sector priorities, regional focus and country choices, identify those major factors that have contributed to those policy changes during the last over half a century in terms of its decision or $\mathrm{so}^{2)}$. The paper ponders 
on possible changes in Japanese ODA policies that may be emerging in the coming decade. The paper also focuses on the changing implementation machinery of Japanese ODA policies, programmes and projects at home and overseas, consultation processes with partner countries and major donors, bilateral and multilateral, M\&E machinery and transparency and accountability instruments.

\section{〈Table 1-1〉 Japanese Reparations Payments and ODA Net Flows to Developing Countries and International Organizations, 1954-2011}

\begin{tabular}{|c|c|c|}
\hline Year & $\begin{array}{l}\text { Total ODA, US } \\
\text { million }\end{array}$ & Occasions \\
\hline 1954 & 0.106400 & Technical assistance upon Joining the Colombo Plan \\
\hline $1954-65$ & $1,012.080$ & Total Amount of Reparations Payments \\
\hline $1959-76$ & 495.78861693 & Semi-Reparations payments \\
\hline 1961 & 105.000 & Establishment of OECF and OTCA \\
\hline 1964 & 244.000 & Joining OECD \\
\hline 1974 & $1,148.000$ & Reorganization of OTCA into JICA \\
\hline 1981 & $3,353.000$ & $\begin{array}{l}\text { Initial-year commitment under the Second Medium-Term } \\
\text { ODA Expansion Plan }\end{array}$ \\
\hline 1984 & $6,500.000$ & $\begin{array}{l}\text { Initial-year commitment under the Third Medium-Term } \\
\text { ODA Expansion Plan }\end{array}$ \\
\hline 1988 & $9,069.000$ & $\begin{array}{l}\text { Initial-year commitment under the Fourth Medium-Term } \\
\text { ODA Expansion Plan }\end{array}$ \\
\hline 1993 & $11,259.000$ & $\begin{array}{l}\text { Initial-year commitment under the Fifth Medium-Term } \\
\text { ODA Expansion Plan }\end{array}$ \\
\hline 2000 & $13,508.000$ & $\begin{array}{l}\text { Initial-year commitment at the U.N. Millennium Summit } \\
\text { Meeting }\end{array}$ \\
\hline & \multicolumn{2}{|c|}{$\begin{array}{l}\text { (On the net disbursement basis: } 0.23 \% \text { of } \mathrm{GNI} \text { ); } \\
\text { (On gross disbursement basis: } \$ 16,300 \text { million); }\end{array}$} \\
\hline 2011 & $10,831.000$ & Tohoku Great Earthquake/Tsunami \\
\hline & \multicolumn{2}{|c|}{$\begin{array}{l}\text { (On the net disbursement basis: } 0.18 \% \text { of GNI); } \\
\text { (On gross disbursement basis: } \$ 19,992 \text { million); }\end{array}$} \\
\hline
\end{tabular}

Sources: Hirono, Ryokichi, 2001, Japan's ODA in the Global Economy: Contributions and Challenges, JICA/JOCV, Komagane Training Centre; and GoJ/MOFA, 2013, White Paper on Japanese ODA, pp.50-53.

2) For detailed discussion on this subject, see Ryokichi Hirono, "Waga Kuni ODA Seisaku no Tenkai: Hanseiki no Sogo Hyoka Shiron (Japan's ODA Policy during the Last Half a Century: An Overall Evaluation), Toshi Mondai Kenkyu (Studies on Urban Problems), October, 2001. 
〈Table 1-2〉 Japan's ODA, 1961-2012

\begin{tabular}{c|c|c|c|c|c|c|c|c|c}
\hline Year & 1961 & 1970 & 1975 & 1980 & 1985 & 1990 & 1995 & 2000 & 2012 \\
\hline Bilat & 95.5 & 371.5 & 850.4 & 1,961 & 2,557 & 6,940 & 12,916 & 9,640 & 10,831 \\
\hline Multi & 11.4 & 86.5 & 297.3 & 1,343 & 1,240 & 2,282 & 1,574 & 3,779 & $(\mathrm{~B}+\mathrm{M})$ \\
\hline
\end{tabular}

Source: MITI, White Paper on Economic Cooperation 1971; MOFA, White Paper on Japan's ODA, relevant years.

\section{Changing ODA Policy Orientation}

\section{1) Basic Philosophy and Principles: ODA Charters Revisited}

The basic philosophy and principles behind Japanese ODA, as repeatedly mentioned in its Blue Paper on Japanese foreign policy and White Paper on ODA White Paper on ODA, have been its emphasis on the self-help and ownership of, by and for partner countries. In bilateral and multilateral discussion and negotiations on ODA ever since 1961, Japan has always expressed its basic philosophy and principles in terms of "assisting those developing countries in their own self-efforts for accelerating economic and social development." This basic philosophy and principle was translated into "the partner country request principle" to which Japanese ODA policy formulation and implementation especially at the bilateral level has had to be adhered to. This basic principle behind Japanese ODA policy has been welcome by all developing partner countries, as the latter has always been sensitive to the principles of self-determination and non-intervention of all countries in their internal affairs.

While holding this basic philosophy and principle in its ODA Charter, however, Japan had to modify its ODA policy priorities in practice, as shown in the revisions of its ODA Charter, in response to global consensus emerging in response to changing domestic and global issues. First in the early 1980s when the Structural Adjustment Policies and Programmes were installed by the IMF and the World Bank in their multilateral assistance under the so-called Washington Consensus, laying down certain list of "conditionalities" to be acceded by borrowing countries. The second shot came in the 
mid-1990s as Japan's ODA volume had to be curtailed in response to the deteriorating economic conditions and especially growing fiscal imbalances at home which forced Japan to be selective in their bilateral and multilateral ODA programmes and allocations. Thirdly in response to the changing ODA policy priorities set by the international community in favour of Human Rights including Child Rights, Basic Education for All, Poverty Reduction, Healthcare for All, Gender Equity and others endorsed at a series of the United Nations-sponsored global summits during the 1990s and eventually by the Millennium Development Goals (MDGs) adopted by the United Nations General Assembly in the fall of 2000. Fourthly in response to the warnings announced by the Inter-governmental Panel on Climate Change (IPCC) in its Assessment Review 4 and now AR 5 issued in October this year.

Thus, Japan's ODA Charter, announced on 30 June 1992, explicitly stated that Japan now stands more than ever ready to assume an international responsibility commensurate with its resource capability for pursuing world peace, maintaining global prosperity and sustaining the global environment through continued assistance to the developing world. Its revised version in 2003 brought in the new dimensions of ODA in favour of assistance to developing countries in conflict prevention and resolution as well as in peace-keeping and-building, in addition to further reiterating the four principles contained in the first ODA Charter, as shown below ${ }^{3)}$.

a) ODA must be extended, taking into account its impact on the environment;

b) ODA must not be used for military purposes or aggravation of international conflicts;

c) Partner countries' misallocation of domestic resources, including high defense spending, the production of weapons of mass destruction and the export and import of arms, must be discouraged;

d) Partner countries' efforts towards democratization, the transition to a market-oriented economy, and the establishment of human rights and political

3) Prof. Akira Nakajima, “Japan's ODA: Present Performance and Tasks Ahead," in Tatsuro Matumae abd Lincoln C. Chen, eds., In Pursuit of Common Values in Asia: Japan's ODA Charter Re-evaluated, Tokai University Press, 1997, p. 37. 
freedom must be encouraged;

Reflecting these changing global ODA policy priorities, Japan redirected its annual consultation machinery as a bilateral forum for encouraging partner countries to fulfill those objectives and goals set by the international community and by Japan's ODA Charter, while still keeping in mind the traditional ODA policy emphasis of Japan on the principle of self-help of partner countries and non-intervention in their domestic affairs. It is important to note in this connection that Japan fully understands some of the criticisms hauled by the civil society organizations (CSOs) and other groups at home and overseas that it is high time for Japan to drop its traditional basic philosophy and principle of non-intervention in the domestic affairs of partner countries, as many of the latter have been reported to have misused their bilateral ODA through corruption and mis-allocation to those sectors which Japanese ODA Charter has always discouraged, such as increasing military expenditures, human rights violation and repression of democratic governance. The steady growth of Japanese ODA to local governments and non-governmental organizations in partner countries through its NGO and grass-roots assistance schemes has been partly a response of Japan to such criticisms. The allocation of Japanese ODA through multilateral development and finance institutions has also been a case in point, as they tend to be much more focused on certain objectives and goals set by the international community and yet without or with a lesser degree of external blames of diplomatic interventions by bilateral donors.

\section{2) Strategic Initiatives in response to Changing Global Issues}

With the growing expectations of the international community toward Japan's rapid economic growth and its position in the global economy, Japan took a number of strategic initiatives in its ODA policies4).

4) For detailed discussion of this subject, see Ryokichi Hirono, "Nihon no Gaiko Seisaku to ODA : Hanseiki no Keiken kara Shorai eno Tenbo (Japan's Foreign Policy and ODA: its Reflections on the basis of the Last Half a Century and Looking Ahead into the Future)" in Kokusai Mondai (International Affairs), No. 548, November, 2005, pp.7-26. 
Reflecting the enormous expansion of foreign exchange reserves resulting from the rapid export expansion of Japanese industry based on its comparative advantages in technological competence, diligence and dedication of their workforce to productivity improvement such as through Kaizen, zero defect and quality control teams on the production floor, the Japanese government made a strategic move in its ODA policy reform first by announcing ODA doubling programme every three years in the late 1970s and every five years in the late 1980s into the 1990s and secondly by reorienting its ODA focus on those critical global issues facing not only developing countries but also the entire world.

The First Medium-Term ODP Expansion Plan was announced in July, 1978 for the fiscal years 1978-80 totaling US\$3.3 billion, followed by the Second Plan announced in January, 1980 for the fiscal years 1981-85 amounting to US\$18.1 billion, by the Third Plan in September, 1985 totaling US\$40 billion for the fiscal years 1986-90, by the Fourth Plan in June, 1988 totaling US\$50 billion for the fiscal 1988-92, and by the Fifth Plan announced in June, 1993 for the fiscal 1993-97 amounting to US\$70-75 billion. Although not all these Expansion Plans achieved the targets, the total amount of Japanese ODA between 1978 and 1996 for the five Plan period reached US\$133.4 billion in contrast to the Plan target of US\$133. 8 billion. As most of the OECD countries spearheaded by the United States began to reduce their ODA flows to developing countries after the breakdown of the Berlin Wall in 1989 and the Soviet Union in 1990, the Japanese initiative of continuing to expand its ODA volume was highly welcome by the international community. At the Millennium Summit meeting, in spite of its GNI already at a low growth rate and often stagnating, Japan announced its international commitment to maintain a high level of ODA annual flows to developing countries, in recognition of the ever growing and diversifying global issues affecting the economic and social development and environmental and domestic security of developing countries

Not only Japan continued to expand its ODA up until 1997 in accordance with its ODA Doubling/Expansion Programme, but also began to announce a series of ODA initiatives successively during the 1990s. All these ODA initiatives were aimed at calling an urgent 
attention of the international community to concerted global action on certain selected global issues identified by the Stockholm Conference on Human Environment in 1972, the Earth Summit in 1992, other global summit declarations in the rest of the 1990s and the Millennium Development Goals (MDGs) adopted by the General Assembly in 2000. As early as in 1986 Japan proposed the enhanced assistance to Community-based Development Initiative (CDI) in response to the meeting of International Union of Local Governments held in Koln in 1985 which later evolved a keen interest and action by municipal governments the world over in international development and cooperation, giving birth to ICLEI. Women in Development (WID, later Gender Equity) was also initiated by Japan for developing countries in 1995 and the strengthening of international Partnership for Democratic Governance in developing countries in 1996. In the following year Japan called for Global Environment and Development Programme in the $21^{\text {st }}$ Century and the enhanced assistance to developing countries promoting the prevention of global warming. Enhanced assistance to Developing Countries Struggling Against Cholera and other Infectious Diseases was also proposed by Japan at the Group of 8 Summit in 1998, as well as the enhanced assistance to developing countries suffering from internal conflicts which later culminated into the International Dialogue for Peace and Nation Building where 44 countries and 8 international organizations participate as well as enhanced assistance to developing countries to narrow the Digital Gap in 20005).

Also, following the Jomtien conference of the UNESCO in 1990, Japan took a series of initiatives for enhanced support to basic education, teacher training and technical education in developing countries which culminated in its initiative of Special Assistance to Education in Low-Income Countries in 2001 and the U.N. Decade on Education for Sustainable Development (UNDESD) at the World Summit on Environment and Development (WSSD) in Johannesburg in 2002. Unlike all the preceding initiatives taken by Japan, the UNDESD proposal adopted at the Johannesburg Summit was the first international resolution proposed jointly by the Japanese government and the civil

5) The MOFA's White Paper on ODA 2004, reflecting Japan's ODA during the last half a century, discusses a number of initiatives taken by GoJ especially in the 1990s. It is notable that few initiatives were taken prior to the 1990s when Japan's ODA was growing by leaps and bound. 
society groups together, as stressed by the then Prime Minister Koizumi, in presenting the proposal at the Summit6). In 2003 Japan proposed for the World Conference on Water and committed itself to enhanced cooperation with all countries, developing and developed, in the maintenance of freshwater supplies at the global level and particularly in dry zones of sub-Saharan Africa.

It is important to note in this respect that not only Japan but also a number of OECD countries took initiatives on a variety of global issues and made concrete proposals for global action. On poverty reduction, the United Kingdom took an initiative and mobilized the support of Group of 8 and the international community, eventually reflected in the MDGs in 2000. On democratic governance, the United States and Nordic countries took an initiative in collaboration with United Nations Development Programme (UNDP) for global action, resulting in the establishment within the United Nations the U.N. Democracy Fund (UNDF). On HIV/AIDS, Japan, the U.S. and EU together with the Republic of South Africa mobilized the support of the international community for global action, culminating into the establishment of Global Fund Against HIV/AIDS and Malaria. All these global initiatives show very clearly that the on-going and emerging global issues could not be solved by a few countries alone, but would require a collaborative and concerted action in partnership with all the other like-minded countries. The 1990s in fact prepared the roadmap for the international community for attempting to solve the global issues in a global fashion, the entry into the Age of Global Partnership.

On the issue of human security the concept of which was strongly enunciated in UNDP-sponsored Human Development Report of 1994, Japan led the international community since 1998 in collaboration with UNDP in support of the global action and

6) Civil society groups organized themselves in 2000 in Tokyo into the Forum for Johannesburg Proposals (FJP), drafted its proposal entitled Education for Sustainable Development for submission to the Government of Japan (GoJ) and requested the GoJ to propose it jointly with FJP at the World Summit on Sustainable Development (WSSD) held in Johannesburg, South Africa in August-September, 2002. For detailed discussion, see Ryokichi Hirono, "Promoting Sustainable Development through Education in the Era of Globalization: A Japanese Perspective," OIKOS International \& Copernicus et al, eds., Proceedings of the Conference on the International Launch in Higher Education, Committing Universities to Sustainable Development, April 2005, Graz, Austria, pp. 14-21. 
setting up within the United Nations secretariat the Human Security Fund (HSF) in March, 1999, in response to the repeated call from post-conflict and -disaster countries for meeting basic human needs such as food, drugs, medical supplies and shelters as well as support to basic education and skills to internal and international refugees in post-conflict countries ${ }^{7)}$. As foreseen, HSF became increasingly significant with the growing number of in-country and international refugees resulting from armed internal conflicts and external interventions especially in Cambodia, sub-Saharan Africa, Iraq and Afghanistan in the 1990s and 2000s. The need for seamless assistance in conflict-ridden and post-conflict countries became keenly recognized and the Japanese initiative for the installation and enhancement of HSF was especially welcome by the international community and appreciated highly by U.N. High Commissioner for Refugees (UNHCR), World Food Programme (WFP) and UNDP8).

On a variety of the global environmental issues EU, Japan, Canada and the U.S. appealed in collaboration with United Nations Environment Programme (UNEP) to the international community for concerted global action. On the prohibition of ozone layer destructive chemicals, Canada and the U.S. took an initiative for mobilizing the support of the international community to concluding Montreal Protocol. On climate change adaptation and mitigation, biodiversity protection and 3Rs, EU and Japan took an initiative for concluding Kyoto Protocol, Biodiversity Convention and Global Network for 3Rs. On the accelerated development of renewable sources of energy, EU and especially Germany and Nordic countries took an initiative for global action at the Rio+10 global summit in Johannesburg, though not resulting in an international agreement as for other global environmental issues.

7) HSF in the U.N. secretariat was intended to reinforce the efforts of U.N. organizations and specialized agencies to respond effectively in collaboration with bilateral donors and NGOs in the affected countries. So far Japan has been its major funder amounting to US $\$ 700$ million, supplemented by a few other Nordic countries.

8) United Nations, 2004 World Summit Outcome, A/60/L.1, New York. 


\section{3) Programme and Sector Priorities, consistent with Global Commitments}

In response to the changing global policy priorities and the changing domestic needs and requirements of partner countries particularly in Asia and the Pacific region, Japanese ODA programme and sector priorities have also undergone enormous changes since 1961.

As shown in Table 2 below, unlike other major donors of the West, a major portion of Japan's bilateral ODA has been going to the development of economic infrastructures such as highway, sea- and air-port, railway, communications, irrigation and electric power generation and distribution facilities. This traditional pattern of ODA allocation was consistent with the request of partner countries which emphasized the expansion and modernization of their economic infrastructures essential to rapid economic reconstruction and industrial development. It also coincided with the Japanese policy preferences based on its postwar experiences whereby infrastructure development had proven to be the key to its rapid economic reconstruction and development. In fact, the Ministry of International Trade and Industry (MITI, later renamed as the Ministry of Economy, Trade and Industry) explicitly stated in its annual publication of White Paper on Economic Cooperation up to 1963 that ODA was an instrument of expanding Japan's manufactured exports and securing natural resources essential to running Japanese industry ${ }^{9}$.

Furthermore, there was a sufficient pool of human, technological and institutional resources available in Japan toward the development of economic infrastructures. In order to make more effective utilization of ODA resources and heighten the impact of such assistance in partner countries, both technical and financial assistance programmes through OTCA (later renamed as Japan International Cooperation Agency-JICA) and OECF (later renamed as Japan Bank for International Cooperation), both established in 1961, began to be coordinated during the 1980s-90s and eventually merged into an expanded new JICA in 2007.

9) See an appendix Chart 1 of Prof. Junichi Inada, "Democracy and Stability: Political Considerations in Japan's ODA to Myanmar and China," in T. Matsumae and L. C. Chen, op.cit., p. 121. 
〈Table 2〉 Sectoral Distribution of ODA by Major DAC Donors, 2000-2011

\begin{tabular}{|c|c|c|c|c|c|}
\hline Sector/programme & Japan & U.S. & U.K & France & Germany \\
\hline Social infrastructure and services & 18.3 & 34.0 & 40.0 & 27.9 & 8.3 \\
\hline Economic infrastructure & 21.7 & 2.2 & 8.4 & 5.0 & 11.9 \\
\hline Transport & $(23.58)$ & & & & \\
\hline Communications & $(0.24)$ & & & & \\
\hline Energy & $(17.42)$ & & & & \\
\hline Banking\&finance & $(0.17)$ & & & & \\
\hline Business support & $(0.08)$ & & & & \\
\hline Production Sector & 3.4 & 19.5 & 4.0 & 7.0 & 12.9 \\
\hline Agriculture & $(5.1)$ & 1.0 & 5.2 & 1.8 & 2.7 \\
\hline Forestry & $(1.56)$ & & & & \\
\hline Fishery & $(0.24)$ & & & & \\
\hline Manufacturing & $(4.25)$ & & & & \\
\hline Mining & $(0.12)$ & & & & \\
\hline Construction & $(0.00)$ & & & & \\
\hline Energy & 0.2 & 13.2 & 14.0 & 6.6 & 3.0 \\
\hline Trade & $(0.57)$ & & & & \\
\hline Tourism & $(0.09)$ & & & & \\
\hline Multi-sector & $(3.13)$ & & & & \\
\hline Other multi-sector & $(6.69)$ & & & & \\
\hline Commodity \& programme aid & 51,3 & 30.1 & 28.4 & 51.7 & 81.2 \\
\hline Debt relief Humanitarian assistance & $(5.78)$ & & & & \\
\hline Aid administration & $(5.27)$ & & & & \\
\hline Total amount in US\$ million & 10,831 & & & & \\
\hline
\end{tabular}

Source: MOFA, White Paper on Japan's ODA, relevant years.

Note: Figures in bracket are those for 2011.

With the enactment in 1971 of the International Assistance Act in the United States which gave its ODA priority to education, health and small-scale irrigation and with the World Bank strategy shifting to meeting Basic Human Needs in the early 70s, Japan, reviewing its traditional ODA programme and sector priorities on economic 
infrastructures, began to reorient its ODA policy in favour of family planning and social infrastructure development such as education and health as well as sanitation. In the 1970s, however, major part of Japanese ODA even in the social infrastructure sector went to the construction of schools, universities, research institutes, libraries, hospitals, nursing and sewerage facilities. Later in the 1980s and 1990s, however, Japan's ODA financial assistance became coordinated with technical assistance for effectively managing and sustaining these facilities such as training and upgrading of school teachers, university researchers and professors, librarians, medical doctors, nurses, hospital administrators and civil engineers and so on.

Japan's ODA programme and sector priorities were further reoriented in the 1990s and 2000s toward the new global issues such as poverty reduction, democratic governance, HIV/AIDS, human security, climate change, biodiversity, three Rs (reduction, reuse and recycling of wastes) and renewable energy development as well as conflict resolution and prevention, peace-keeping and-building in response to the urgent calls enunciated by a series of global summits convened by the United Nations ${ }^{10)}$. The permanent members of the U.N. Security Council all of which own a substantive proportion of the world's nuclear weapons took an initiative of concluding Nuclear Non-Proliferation Treaty, Nuclear Test Ban Treaty and others, leading to the increased allocation of bilateral and multilateral ODA for peace maintenance, together with the Landmine Prohibition Treaty and other international initiatives by international NGOs for human security and conflict prevention.

Thus, various international treaties, protocols, conventions and agreements signed by developed and developing countries in the 1990s created their respective secretariats and opened new avenues for multilateral ODA, including the installation of Global Environment Facility, Carbon Credit Facility, Climate Change Fund and so on. Japan, being a signatory to these international treaties, protocols and agreements, increased its ODA allocation to these global funds and funds in trust. While these multilateral

10) Ryokichi Hirono, "Reorienting International Development to Accelerate Poverty Reduction and Ensure Sustainability as the Century's Top Development Goals," International Review for Environmental Strategies, vol.4, No.1, Summer 2003, pp. 21-44. 
funds are useful in focusing on specific tasks of the international community and improving the effectiveness of ODA in those specialized fields of international assistance, there is a mounting concerns among donor communities and partner countries alike on the multiplicity of specialized secretariats, suggesting, as for example in international environmental cooperation, a need for integrating all these secretariats into one like under the umbrella of UNEP.

In spite of these dramatic changes in Japanese ODA policy orientation during the last half a century, one feature of Japanese ODA policy which remained unchanged during the last 60 years or so has been its constant emphasis on the development of technical, skilled, engineering, professional and managerial manpower essential to operating and managing those economic and social infrastructures in all programmes and sectors ${ }^{11)}$. The development of these human resources has been promoted through inviting a few thousand trainees annually from public sectors including local government and independent government agencies and accommodating over a thousand graduate students annually in Japanese universities on the basis of ODA and private foundation scholarships. In addition, a few thousand trainees and interns have been invited annually from private industry and non-government organizations in partner countries for upgrading their operating skills and managerial competence. These trainees and interns invited on Japanese technical assistance programmes are often those engaged in or associated with large-scale Japanese loan and grant assistance programmes and projects in partner countries so that they would be able, upon returning home. to operate their machinery and equipment efficiently and/or manage their work effectively often, but not always, under the supervision of Japanese engineers and managers assigned under Japanese technical assistance programmes. The total number of those trainees and interns in partner countries invited to Japan on its technical assistance programmes has now reached over half a million as of October, 2013.

In order to effectively formulate and implement Japanese ODA, it was also felt keenly

11) Ryokichi Hirono, "Japanese Assistance for Human Resources Development in ASEAN Countries," in Thailand Human Resources Foundation, Report of the Conference on Human Resources Development in ASEAN, held in Bangkok in March, 2001. 
important to develop in Japan manpower in terms of professional expertise, communications skills and practical experiences. For this purpose the Japan Society for International Development (JASID) was installed in March, 1990 to bring academia, researchers, consultants and practitioners together to be engaged in constructive dialogue among them as well as to promote studies and research on international development and cooperation. Also, the Foundation for Advanced Studies in International Development (FASID) was established in April, 1990 to provide a number of programmes to train those government officials engaged in international cooperation, train young students for advanced studies at graduate schools at home and overseas, to promote research on urgent issues of international development and cooperation. As part of such efforts, Graduate Institute for Policy Studies (GRIPS) and other graduate institutions were also established at a number of universities all over the country. JASID and its leadership took initiatives in all these national efforts to increase the number and improve the quality of Japanese practitioners, professionals and scholars engaged in international development and cooperation ${ }^{12)}$.

\section{4) Dramatic Changes in Regional Focus}

Just as in programme and sector priorities, there has been a significant change in the regional focus of Japanese ODA programmes since 1961. As shown in Table 3-1 below, an overwhelming majority of Japanese ODA flowed to the Asian and Pacific region during the earlier years of 1960s and 1970s, but its allocation to the region as percent of the total ODA disbursements has steadily declined over the years, reaching less than 40 percent in 2012. It is to be noted, however, that ever since 1961, Asian countries have consistently been among the top four largest recipients of Japanese ODA except in 2005 and 2009, when Iraq and Turkey respectively was among the largest four due to the urgent call of the international community, as shown in Table 3-2 below.

12) FASID in collaboration with JASID and MOFA and the Ministry of Education acted not only as promoters of model teaching curricula at those universities establishing those graduate training programmes in international development and cooperation, but also by funding their programmes for sending out graduate students overseas for on-site observation and internship in international organizations. 
〈Table 3-1〉 Regional Allocation of Japanese Bilateral ODA, 1965-2011

\begin{tabular}{l|r|r|r|r|r|r|r|r}
\hline & \multicolumn{1}{|c|}{1965} & \multicolumn{1}{|c|}{1970} & \multicolumn{1}{|c}{1980} & \multicolumn{1}{c}{1990} & \multicolumn{1}{c}{2000} & \multicolumn{1}{c}{2005} & \multicolumn{1}{c}{2010} & 2011 \\
\hline Asia & 90.9 & 98.2 & 70.5 & 59.3 & 54.8 & 36.7 & 53.1 & 48.9 \\
\hline Middle East & 0.2 & 3.6 & 10.4 & 10.2 & 7.5 & 33.2 & 16.3 & 11.7 \\
\hline LACs & 8.7 & -4.0 & 6.0 & 8.1 & 8.2 & 4.0 & 8.8 & 5.3 \\
\hline Africa & 0.2 & 2.2 & 11.4 & 11.4 & 10.1 & 10.8 & 12.0 & 20.1 \\
\hline Oceania & 0.0 & 0.0 & 0.6 & 1.6 & 1.6 & 0.9 & 1.3 & 1.2 \\
\hline CEE & 0.1 & 0.0 & ins. & 2.3 & 1.2 & 3.1 & 1.5 & 1.8 \\
\hline Others & ins. & 0.3 & 1.2 & 7.1 & 16.5 & 11.4 & 10.2 & 11.3 \\
\hline
\end{tabular}

Source: MOFA, White Paper on ODA, relevant years

〈Table 3-2〉 The largest recipients of Japanese ODA, 1975-2009

\begin{tabular}{r|lr|lr|lr|lr}
\hline Year & \multicolumn{7}{|c}{ Top Four (US million) } \\
\hline 1975 & Indonesia & 197.9 & ROK & 87.4 & Philippines & 70.3 & Malaysia & 63.3 \\
\hline 1980 & Indonesia & 350.0 & Bangladesh & 215.1 & Thailand & 189.6 & Burma & 152.5 \\
\hline 1985 & China & 387.9 & Thailand & 264.1 & Philippines & 240.0 & Indonesia & 161.3 \\
\hline 1990 & Indonesia & 867.8 & China & 732.0 & Philippines & 647.5 & Thailand & 418.6 \\
\hline 1995 & China & $1,380.0$ & Indonesia & 892.4 & Thailand & 667.4 & India & 506.4 \\
\hline 2000 & Indonesia & 869.1 & China & 686.1 & India & 528.9 & Vietnam & 459.5 \\
\hline 2005 & Iraq & $3,502.9$ & Indonesia & $1,233.1$ & China & $1,064.3$ & Vietnam & 602.7 \\
\hline 2009 & Vietnam & $1,191.4$ & India & 517.0 & Turkey & 210.8 & Afghanistan & 170.5 \\
\hline
\end{tabular}

Source: MOFA, White Paper on Japan's ODA, relevant years.

Several factors have been responsible for this salient feature of Japanese ODA's regional focus and its dramatic change in 2000 onward. In the 1960s and 1970s Japan's ODA priority allocation to Asia and the Pacific region lay in the fact that first, because of Japan's wartime acts, Japanese people felt their obligations to assist those Asian and Pacific countries struggling out of poverty and underdevelopment, and secondly because of historically close trade and economic relations with them, Japanese industry hoped for a rapid economic reconstruction of the region which would be beneficial to their growing need for manufactured exports and raw materials imports, and thirdly because of the alliance with the United States against communist infiltration GoJ was keenly interested in quickly restoring peace and development and thus ready in 
providing bilateral ODA, as well as setting up Asian Development Bank (ADB) in 1965 in collaboration with the United States and other like-minded donors for additional multilateral funding for non-communist countries in Asian and Pacific region. It may be noted in this respect that not only Japan, but all the other major donors were directing a sizeable portion of their respective ODA flows to non-communist countries of this region up to 2000, as shown in Table 3-3 below, although it is to be admitted and understandable that major European donors such as France, Germany, Italy and U.K. have been providing major part of their ODA to their former colonies of Africa, Asia and the Middle East.

〈Table 3-3〉 Regional Allocation of Bilateral ODA by Major Donors, 1988-2011

\begin{tabular}{l|r|r|r|r|r|r|r|r|r}
\hline & \multicolumn{3}{|c|}{ LACs } & \multicolumn{3}{c|}{ Africa } & \multicolumn{3}{c}{ Asia } \\
\cline { 2 - 11 } & 1988 & 2000 & 2011 & 1988 & 2000 & 2011 & 1988 & 2000 & 2011 \\
\hline France & 3.2 & 4.0 & 13.5 & 59.7 & 55.9 & 51.8 & 37.1 & 40.1 & 13.0 \\
\hline Germany & 12.9 & 12.5 & 12.9 & 41.2 & 32.4 & 29.5 & 45.9 & 55.1 & 28.8 \\
\hline Japan & 7.3 & 8.0 & 5.2 & 18.1 & 12.1 & 20.1 & 74.6 & 79.9 & 48.9 \\
\hline Netherlands & 18.3 & 9.3 & 1.0 & 36.3 & 24.5 & 13.4 & 45.4 & 66.2 & 6.6 \\
\hline U.K. & 6.0 & 10.4 & 1.9 & 46.2 & 39.5 & 40.2 & 47.8 & 50.1 & 22.9 \\
\hline U.S.A. & 18.0 & 17.0 & 9.1 & 26.3 & 28.6 & 34.7 & 55.7 & 54.4 & 21.6 \\
\hline
\end{tabular}

Sources: OECD/DAC, Development Cooperation Report, relevant years.

Note: The balance are ODA to the other regions including unspecified.

A number of notable developments took place in Asia and the Pacific region during the last few decades which brought dramatic change in Japan's regional focus in ODA. First, in the 1980s and 1990s most countries of East Asia such as many of the Association of South East Nations (ASEAN) countries, China and the Republic of Korea (ROK), had an enormous success in economic and social development, with the consequence of their need for ODA declining steadily and significantly over the years, as shown in Table 4 below..

In fact, there have been no new Yen loans extended to China since 2007, although technical assistance is still going on, and no ODA to ROK since 1990. Second, having become a global economic power by 1980s, far exceeding per capita GNI of major 
European countries, Japan was requested by OECD donor community and the rest of the international community to assist low income and least developed countries the world over, especially in sub-Saharan Africa and Eastern European countries in transition to market-oriented economy. Third, new donors such as Brunei, China, India, Malaysia, ROK, Singapore and Thailand, have emerged in Asia and the Pacific region in the 1990s and 2000s, with the consequence of the late comers of ASEAN such as Cambodia, Lao, Myanmar and Vietnam and of the South Asian Association for Regional Cooperation (SAARC) such as Bangladesh, Bhutan, Maldives and Nepal receiving financial and technical assistance from these emerging donors.

\section{〈Table 4〉 Economic Growth and per Capita GNI by Regions and by Selected Countries, 1970-2010}

\begin{tabular}{l|r|r|r|r|r|r}
\hline \multirow{2}{*}{ Region } & \multicolumn{4}{|c|}{ Annual growth rate } & \multicolumn{2}{c}{ Per capita GNI,PPP } \\
\cline { 2 - 7 } EAP & $1970-80$ & $1980-90$ & $1990-2000$ & $2000-10$ & 2000 & 2010 \\
\hline China & 6.6 & 7.7 & 7.2 & 9.4 & 4,170 & 6,623 \\
\hline ROK & 5.2 & 9.4 & 10.3 & 10.8 & 3,940 & 7,570 \\
\hline ECA & 9.6 & 9.6 & 5.7 & 4.1 & 17,340 & 29,010 \\
\hline LACs & 5,1, & 1,5 & -1.6 & 5.4 & 4,120 & 13,700 \\
\hline MENA & 5.5 & 1.7 & 3.3 & 3.8 & 6,620 & 10,951 \\
\hline SA & 3.2 & 2.1 & 3.0 & 4.7 & 5,170 & 7,857 \\
\hline SSA & 4.0 & 5.4 & 5.6 & 7.4 & 2,360 & 3,208 \\
\hline HICs & 3,2 & 2.1 & 2.4 & 5.0 & 1,560 & 2,108 \\
\hline World & 3.5 & 2.9 & 2.4 & 1.8 & 27,450 & 37,183 \\
\hline
\end{tabular}

World Bank, World Development Report, relevant years.

An increasing allocation of ODA to sub-Saharan Africa by Japanese and other major donors also reflected a consensus reached in the 1990s among the OECD countries to allocate at least $25 \%$ of their ODA to least developed countries which were by far found in sub-Saharan Africa as well as a global consensus on the reduction of absolute poverty endorsed by the international community in its Millennium Development Declaration adopted in 2000. It is interesting to note in this connection that due to 
differences in the domestic preconditions between countries of sub-Saharan Africa and East Asia that the latter has been able to achieve much faster economic growth and greater increases in per capita GNI than the former and that many donors seem to have come to conclusion that it was due to better governance and political stability of East Asian countries that have made it possible for them to move forward thus far.

\section{5) Changing Panorama of Country Focus: Tug of War between Global Preferences and Diplomatic Priorities}

Since Japan, adhering to its basic philosophy and principle in ODA policy formulation, has always given priority to the principle of Self-Help and the sense of Ownership of developing countries, the Structural Adjustment Policy of IMF and the World Bank in the early 1980s and 1990s that emphasized economic policy reform and structural adjustment in developing countries came as a reassurance to ODA policy planners of Japan, but also gave a headache to them.

On the one hand the Bretton Woods Institution's SAPs gave an impetus to Japan to bring in a certain general policy framework in providing its ODA in terms of country choices so that those countries acceding to SAPs would benefit preferential treatment in Japanese ODA policy formulation. As a result, the declining flows of its ODA could be more effectively utilized in the eyes of ODA policy planners in MOFA and policy practitioners in JICA as well as those civil society groups critical of Japanese ODA policies at home and overseas as being "unprincipled and non-committed." On the other hand, there were those foreign policy planners within MOFA who had adhered to the traditional principle of non-intervention to which Japan had long observed at least since the end of World War II and who interpreted the SAPs as a clear case of intervention in the domestic affairs of partner countries, thus opposing to the strict adherence to, and let alone to strict application of the SAPs in actual implementation of Japanese ODA administration.

There were other reasons for opposition to the use of SAPs as a criterion of country choices in Japanese ODA policy formulation. Knowing fully well the strong opposition of developing countries to the imposition of any elements of "conditionalities" by the 
IMF/World Bank in providing multilateral assistance, many of the MOFA officials engaged in Japan's foreign policy formulation were concerned with the adverse impact of such country choice criteria on their efforts to urge and persuade the developing countries to support Japan's bid to reform the U.N. Security Council and in particular to bring Japan together with Brazil, Germany, India and South Africa as semi-permanent members of the Security Council. There was also a strong opposition coming from those officials of the other substantive ministries trying to increase their respective shares of Japanese ODA administration who feared possible reduction of ODA in their respective sectoral programmes and in those countries receiving ODA and thus recommended MOFA to go slow in the use of the SAPs as country choice criteria and, for that matter, the application of the ODA Charter in their ministerial ODA policies.

The introduction of the ODA Charter in 1992 could in fact be interpreted as a result of these tugs of war within the GoJ and especially within MOFA and between MOFA and other substantive ministries. In practice, in the formulation of ODA country choice policy as well as in the implementation of the ODA Charter, there has neither been so far a strict application of the ODA Charter in terms of country choice nor substantial reduction in the number of partner countries receiving Japanese ODA. Japan has continued to provide varying amount of ODA to as many as over 160 countries even today, although its programme and sector priorities have been much more clearly defined and although its bilateral ODA negotiations began to stress on the other hand to stress the need for developing partner countries to respect the human rights of all citizens including child rights and gender equity, adhere to democratic governance, a steady shift to market-oriented national economy and policy reforms, the resolution of domestic and external conflicts through peaceful negotiations rather than arms, prohibition of the use of chemical and other WMD and so on, as spelt out in the ODA Charter.

While Japan as the only country in the world exposed to the atrocities of nuclear bombs in Hiroshima and Nagasaki in 1945, together with many non-nuclear countries, successively introduced at the U.N. General Assembly a resolution on the banning of 
nuclear weapons, this issue has not been given attention in Japan's country choices in ODA, as exemplified in its large ODA flows to China, India and Pakistan. It was given a due attention only when those developing countries made nuclear bomb tests, causing Japan to suspend its ODA in some ensuing months. In October of 2013 Japan joined 128 countries in signing the U.N. policy recommendation on the banning of the use of nuclear weapons as a crime against humanity. All those nuclear powers sitting as permanent members of the U.N. Security Council, China, France, Russia, U.K. and the U.S. did not sign this policy recommendation, joined by India and Pakistan.

\section{Implementation Dynamics}

\section{1) ODA Policy and Implementation Decision Machinery}

One of the most notable reforms of Japanese ODA policy formulation and implementation processes including monitoring and evaluation $(\mathrm{M} \& \mathrm{E})$, research and public affairs activities lies in the dramatic changes that have taken place in its decision machinery.

In the early years of the 1960s and 1970s, the Japanese system of ODA policy and implementation was an internal matter to the GoJ, especially MOFA which had inherited its authority not in the form of law but in practice from those days when Japan's reparations payments under the San Francisco Peace Treaty obligations had been carried out by MOFA in consultation with other substantive ministries. The reparations payments were carried out without questioning at all in accordance with the list of proposals coming from those developing countries entitled to request the GoJ for such "claims." Japan's ODA provision was simply following the precedent of reparations payments request of those partner countries, and carried out in consultation with requesting countries in respect to the details of such request in terms of the type and volume of commodities and services, the time schedule and mode of delivery. As time went on, there were a variety of reform proposals coming from industry associations, corporate executive organizations, independent research institutions, academia. consultant firms and civil society groups with respect not only to the machinery and decision processes 
for ODA policy formulation and implementation, but also the validity of "the request basis," adhered to by MOFA in carrying out its ODA programmes and projects ${ }^{13)}$.

Most salient points of criticisms of the Japanese system of "request-based" ODA provision lay in the accusation by many civil society groups that those so-called requests by partner countries had been engineered by private trading and consulting firms in consultation with the politicians and government bureaucracy of partner countries and had thus not necessarily represented the real needs and requirements of the people in partner countries. Since ODA policies were decisions based on government-to-government negotiations, and since government negotiations and decisions were influenced by those vested interest groups both in aid giving and receiving countries, there was some truth to such criticisms coming from civil society groups. Such criticisms would apply not only to the Japanese system, but also to the ODA administration system of all other OECD countries and possibly all emerging donors. It is fair to say, however, that nobody knows exactly about the extent of corruptive practices and social cost incurred that have been affecting ODA policy and implementation stages in all these countries on both sides.

In this respect it is important to note that Japan and most other donors have already begun to involve local governments and civil ociety groups within both donor and partner countries in the decision processes of ODA policy formulation and implementation either by setting up a National Consultative Group involving representatives of those stake holders outside the central government in donor countries and/or by increasing their ODA flows directly to local governments and CSOs in partner countries,

13) One after another, different stakeholders involved in Japanese ODA policy formulation and implementation made public their reports and proposals for Japanese ODA reforms. One type of such recommendations were on the Japanese ODA policies themselves and their development effectiveness, as referred earlier in Section 2, but many others were on the way decisions were made on ODA policies and implementation. Most early attempt on ODA policy reforms was exemplified by Keizai Doyukai, Japan and the United States in Development Assistance to Southeast Asia, Tokyo, KD and Washington, D.C: CED, 1971. Most recent such studies on ODA policy and implementation reform of Japanese ODA was a substantive study conducted $n 1999$ by a group of JICA young staff entitled "21 Seiki no JICA no Arikata ni tsuite (In Search for a new JICA in the $21^{\text {st }}$ Century)," and another similar study made public in February, 2006 by a group of young MOFA staff entitled "Kaigai Keizai Kyoryoku no Arikata ni tsuite (In Search for Japan's Overseas Economic Cooperation Tomorrow). 
as shown in Japan's Grass-roots Assistance Programme (Initially called Small-scale Assistance Programme) initiated in Japan in the 1990s.

Political parties have been increasingly involved in the decision processes on ODA policy formulation and implementation through their parliamentary debates at ODA Committee meetings and Administration Oversight Committee meetings in both Houses. Their involvement has been confined, however, often to those ODA policy issues and those ODA projects that have been widely reported in mass media as having been branded as failures and/or misappropriated and exposed to corruption in Japan and overseas. As the ODA Charter has stated explicitly on the need for avoiding the use of Japanese ODA for military purposes, the dispatching of Japanese engineers and technicians, the commissioning of ODA projects to CSOs in conflict areas, as in Iraq and Afghanistan, and the shipment of telecommunications and marine and land transport equipment and components which could be used as part of the defense capacity building in partner countries are the case in point. Also, in recent years Japanese ODA allocation to India and Pakistan has been criticized on the ground that both countries have not become party to Nuclear Non-Proliferation Treaty, while political parties did welcome the GoJ's decision in accordance with the ODA Charter to suspend its ODA immediately after China, India and Pakistan went on to test their nuclear weapons.

\section{2) Consultation with Partner Countries}

Reflecting repeated criticisms against the "recipient-based" ODA policy formulation voiced by CSOs in partner countries and donor community, GoJ has begun to engage in serious consultation with partner countries before making decisions on ODA allocation between different programme and sector priorities, alignment to Japan's ODA Charter and governance issues such as fight against corruption and the involvement of and accountability to different stakeholders in partner countries, while of course adhering to the OECD/DAC principles of ODA policy formulation in accordance with the Ownership of partner countries, Alignment to their long-term development programmes and priorities, Coordination with other donor countries and multilateral assistance institutions, and Outcome-based ODA evaluation. 
Based on a series of recent White Papers on Japanese ODA, GoJ appears to have been satisfied with the results of a growing number of bilateral consultations with partner countries as exhibited in the performance of ODA programmes and projects in many of these countries in all regions, particularly in many sub-Saharan African countries. The fifth Tokyo International Conference on African Development (TICAD V) was convened in the summer of this year, which on the basis of recent achievements in economic growth and political stability recommended further actions in the development of agriculture, resources, small-scale industries, export and tourist sectors as well as for promoting democratic governance and global action to fight against HIV/AIDS and global warming resulting in desertification and soil degradation. The Small-scale Island Developing Country Summit which Japan has been convening for the last decade or so concluded in October this year and called for further global actions for climate change adaptation and mitigation as well as for enhanced assistance to education, health and tourist development.

One of the greatest challenges facing today in the strengthening of consultation machinery with partner countries seems to lie in improving the consultation at the regional level, as partner countries in Asia and its sub-regions have been competing on the region- and world-wide markets to expand their exports and secure essential imports for their own citizens. Also, as shown in the repeated transmission of China's Yellow Dust and PM2.5 impacting adversely on the lives of the people in neighboring countries in recent years, bilateral consultation alone between those parties concerned has proven to be unfair and less effective in dealing with the issues, as it might entail some legal actions. For this reason, there is an urgent need for bringing the issues on the multilateral agenda at the regional level and formulating a regional cooperation agreement signed by all countries concerned in the region, sharing the cost incurred by all on some equitable basis.

\section{3) Coordination among Major Bilateral Donors and Multilateral Development Institutions}

Close consultations among major bilateral donors and multilateral development and 
finance institutions have long been taking place through regular meetings of OECD/DAC. Such consultation includes among others, a) sharing information on ODA policy formulation and implementation, b) establishing the common criteria for ODA policy priorities and outcome evaluation at the policy, programme and project levels, c) formulating common rules of the game, so to speak, for classification of partner countries eligible for ODA allocations, d) determining the terms and conditions of providing ODA to different types of partner countries, e) conducting joint review exercises on ODA policies and programmes of OECD/DAC member countries, and $\mathrm{f}$ ) identifying joint solutions to emerging issues of ODA policy formulation and implementation. Such consultation has been found extremely useful in establishing policy coherence among major donors between ODA on the one hand and trade and investment on the other. It has also proven to be quite effective in the past in reducing unnecessary and expensive competition among them in an effort to bring partner countries into their respective sphere of influences and also during those days of the East-West Cold War regime to bring partner countries into their political alliances.

There have also been bilateral consultations between Japan and other major bilateral donors such as the U.S., U.K., Germany, France, Canada and Australia among others for exchanging information related to ODA policy and implementation experiences and issues and working out joint solutions to certain ODA policy and implementation issues. With a growing size of ODA programmes and projects in partner countries, bilateral consultations among major donors and multilateral institutions have worked well in establishing and managing ODA consortia.

In addition to these regular meetings at $\mathrm{OECD} / \mathrm{DAC}$ and elsewhere, coordination among bilateral donors and multilateral development institutions has also taken place at the so-called pledging conferences, as shown during the last two decades or so for Cambodia, Iraq, Afghanistan, Mozambique and South Sudan, as well as for many decades under the World Bank Consortia meetings for many developing countries. Japan has often taken initiatives in consultation with Australia, New Zealand and the United States in these coordination meetings when involving Asian and Pacific developing countries. 


\section{4) Reorganization of Operational Modalities for Greater Impact}

With an increasing number of technical assistance programmes and projects undertaken by Japan International Cooperation Agency (JICA) spread widely in different countries all over the world and in a wider variety of economic, social, environmental and cultural sectors, and with the size and complexity of the loan assistance programmes and projects financed by Japan Bank for International Cooperation (JBIC) ever growing, it has become evident in the eyes of GoJ and especially MOFA as the coordinating ministry of Japan's ODA policies and programmes that better coordination between technical, grant and loan assistance programmes and projects would enhance the impact of Japanese ODA policies and programmes in partner countries in whatever sectors they operate.

In the process of the entire reorganization in 2001-2002 of all government ministries and the creation of independent agencies to implement government policies and programmes with a view to enhancing both policy coherence and government effectiveness, serious consideration was given under Koizumi Administration to various proposals made by policy think-tanks and academia for merging the two agencies for international cooperation for greater impact in developing countries. The merger between JICA and a part of JBIC engaged in drafting and implementing government loan assistance programmes was finally decided by the Cabinet in 2005, while the other portion of JBIC, inheriting its official name, was charged with providing long-term commercial loans to development projects in developed and developing countries around the world.

The first series of attempts made by the newly reorganized JICA were: a) to facilitate changes in the mentality of the former JICA and JBIC staffs to cooperate with each other and coordinate their assistance policies, programmes and day-to-day practices as soon as possible, b) to decentralize the operational modality of new JICA to local representative offices in partner countries, c) to encourage the latter to work closely not only with the Japanese embassies overseas but also with the government and all the other ODA stakeholders in partner countries, including embassies and aid agencies 
of foreign countries, local and international CSOs and local universities and research organizations, d) to engage in collaboration with local experts in outcome-based monitoring and evaluation, and e) to set up a central research institute to innovate new approaches to ODA policy formulation and implementation and deepen the impact of Japanese ODA performance. Though slowly but steadily the effects of the JICA/JBIC reorganization of 2005 has been being felt in partner countries in enhancing policy

coherence and coordinating, and in some cases, integrating technical, grant and loan assistance projects for greater impact.

\section{5) Monitoring and Evaluation (M\&E) for Better Planning and Programming}

While it is true that both former JICA and JBIC have conducted M\&E for all their ODA activities at the project level since 1970s and that MOFA did it selectively for sector and country programmes since 1980s, several innovations have been installed by MOFA since 1990s on the substance and approaches to effective M\&E. Already in 1996, upon the recommendations of the MOFA's ODA Evaluation Committees, ODA Evaluation Review Panel was set up and presented in 1998 a comprehensive report on the reform of Japan's ODA evaluation system to the Minister of Foreign Affairs, followed by a variety of measures to improve the width and depth of ODA evaluation in Japan. The MOFA's annual evaluation report, although always supplemented by those annual evaluation reports by JICA and JBIC, also began to install its grading system in the 1990s to induce further improvement in the quality of ODA projects implemented by JICA and JBIC in collaboration with consulting and audit firms as well as the academia. In 2002 the Policy Evaluation Act (PEA) was legislated under the strong leadership of Prime Minister Koizumi, requiring all government ministries and their independent implementation agencies to conduct annually policy evaluation for all the overall policies and sub-policies under their respective authority and supervision. To ensure independence of their policy evaluation, they were required to install external evaluation committee consisting of evaluation professionals and representatives of other stakeholder groups, in addition to internal evaluation committee organized by their respective policy evaluation divisions set up under the PEA 200214).

14) For details of the changing feature of Japan's M\&E, see Naonobu Minato and Nobuko Fujita, eds., 
The M\&E activity of MOFA has also been given a greater degree of independence by taking its M\&E office out of the Bureau for International Cooperation engaged in policy formulation to the ministerial secretariat under the Minister of Foreign Affairs, one step removed from policy bureau. Thirdly, there has been a steady increase in the number of country programme and issue-oriented evaluation. Fourthly, evaluation at project, programme and country levels has been reoriented from input-based to outcome-based to measure their impact. Lastly, but not in the least, a greater emphasis has been placed on the feedback of evaluation results to new policy planning and programming, as exhibited in recent ODA Evaluation Reports by MOFA.

\section{6) Transparency and Accountability for Greater Efficiency and Equity}

In response to a growing demand coming from civil society groups and other stakeholder groups at home and overseas, the Diet of Japan enacted the Law on Public Information Disclosure in 1993 in accordance with the global movement for the People's Right to Know in the 1990s so that much of the debates that had undergone within the Executive Branch of GoJ including Cabinet decisions became transparent to the public. The debates in both the House of Representatives and the House of Councilors have been known to the public through their regular records of discussion published ever since the new Constitution of 1947.

Although transparency and accountability debates became active in Japan in the 1990s, it is important to note that MOFA decided as early as in 1981 to publish its annual evaluation reports after intensive debates within the ministry and especially in its ODA Evaluation Committee headed by the director-general of the Bureau for Economic Cooperation (BEC, now renamed as Bureau for International Cooperation). The MOFA's official evaluation report was based on the analyses of all those project evaluation

Evaluating Development Assistance: A Japanese Perspective, Tokyo: Foundation for Advanced Studies on International Development (FASID), 2009, Ryokichi Hirono, "Reflections and Moving Forward in Results-based Policy Review and Budgeting: Case of Japan," presented the Malaysian Evaluation Society's (MES) $5^{\text {th }}$ International Evaluation Conference 2012 held in Kuala Lumpur on 10-14 September, 2012 and Ryokichi Hirono, "A Long Unfinished Journey for Effective Evaluation: Lessons from Japan and Asia," presented at the Sri Lanka Evaluation Society's (SLEVA) International Conference at Mount Lavinia Hotel, Sri Lanka on 23-25 July, 2013. 
reports in the beginning and all those project, sector/programme and country evaluation reports later. The issue of transparency and accountability had been repeatedly taken up in the internal debates of MOFA, beginning with the decision process affecting ODA policy formulation and implementation, thus resulting in the installation as early as in 1978 of ODA Council, advisory committee to the director-general of BEC, composed of representatives of the academia, public think-tanks and the mass media, working closely with the ODA Evaluation Committee of MOFA when established in 1979. In March, 1985 the first White Paper on Japan's ODA was published by MOFA, based upon the recommendation of ODA Council to respond partly to the rising demand for transparency and accountability from CSOs at home and overseas, long before the enactment of Public Information Disclosure Law of 199315).

While it is true that the issue of transparency and accountability has contributed to further improvement in the quality of Japanese ODA performance in partner countries, the reality still remains that the latter depends in major part on the political leadership of partner governments and the capacity of ODA implementation at the central and local government levels as well as those stakeholders engaged in ODA project implementation in partner countries. This has led the GoJ over the years to enhancing its technical assistance programmes of training not only government officials but also all the other stakeholders related to ODA administration and performance in partner countries. It is hoped that, as Partnership for Democratic Governance (PDG) of Japan has emphasized since its establishment in 2003, together with ADB, UNDF, UNDP, World Bank and other international organizations and NGOs, good governance shall prevail in all countries, especially in those partner countries where their Governance Indicators have still lagged behind ${ }^{16)}$.

15) It is fair to say that the first White Paper on Japan's ODA was made public by MOFA in 1985, partly because there had been an anxiety among MOFA officials on the tone of the White Paper on Economic Cooperation published by MITI in its reference to ODA, as an instrument for export expansion and a steady procurement of natural resources.

16) In 2004 PDG's predecessor organization entitled Asian Democratic Partnership (ADP) Committee, on the board of which the author sat as its chair, has organized one international conference in Tokyo with the support of the GoJ and UNDP and two workshops in Cambodia and Mongolia. Followed by another in 2006 in Thailand to assist local CSOs in these countries to promote good governance. For details, see Ryokichi Hirono, ed., Enhancing Democratic Governance in East Asia: Empowering People 


\section{Quo Vadis}

In spite of all these progresses shown in the ODA policy and implementation reforms in Japan, it is disturbing to observe some of the recent reports on the future of ODA. In an survey taken in March 2009 by the Association for the Promotion of International Cooperation (APIC) in Tokyo, one of the NGOs on the board of which the author sits, 82.8\% of the respondents replied that ODA was not known well among the Japanese people, and that as high as $32.3 \%$ of the respondents expressed objection to further expansion of Japanese ODA, while the same percentage of the surveyed supported the current level of ODA. There were only as low as $12.7 \%$ of the respondents who favoured ODA expansion in the future. These responses are truly contrary to those responses obtained in the same survey a decade ago17).

Also, according to the mass media, a majority of youth in Japan today are less concerned with international affairs and especially the role of ODA in solving global issues affecting developing countries ${ }^{18)}$, while a large part of the global issues such as climate change and the depletion of natural resources including the destruction of rainforest reserves have been caused by the unsustainable patterns of mass production, consumption and wastes in developed countries and increasingly by some emerging countries today. Under economic, social, environmental and cultural globalization in today's world, no country can avoid the impact of national policies of other countries, particularly if the latter is major powers. We all live on one boat floating in a turbulent sea, and must work together to overcome any prospects of threats coming internally

and Institutions for Building Sustainable Society, May, 2004; ADHOC and ADP, eds., Report of the Workshop on Democratic Governance in Cambodia, November, 2004; MNWNGO and ADP, eds., Report on Democratic Governance and Civil Society Participation in Mongolia, November, 2004; and AlHR and ADP, eds., Report of the Workshop on Democracy and Good Governance in Thailand, March, 2006, Also see various reports published by PDG up to now.

17) APIC, 2009, Kokusai Kyoryoku ni kansuru Chosa Hokokusho (A Report on International Cooperation), Tokyo: APIC, 2009, pp.14-15 \& 26-27..

18) Asahi Newspaper, Morning Edition for Tokyo, 1 November, 2013, p. 34, deploring a fast decline in the number of Japanese youth applying for Japan Overseas Cooperation Volunteers and positions in international organizations, in spite of the quota for Japan continues to be 4 times as high as the number of those staff of Japanese nationality. 
or externally.

While it may be certain that Japan's ODA will not see a sizeable expansion in the rest of 2010s, it is equally obvious that serious efforts, as shown in the above sections 1 and 2, will continue not only in MOFA and the reorganized JICA, but in all ministries of the GoJ and other stakeholders, as the Cabinet grips on improving the Policy Evaluation of all the government ministries and independent implementation agencies -will continue to grow in response to the rising demand from various civil society groups including private sector for further improvement in government performance and also in response to growing budget deficits of central and local governments. There is also no doubt that all civil groups, academic groups and think-tanks in Japan engaged in international development and cooperation in one way or another will also continue to explore alternative paths of ODA policy and implementation reforms and alternative roadmaps for implementing such ODA reform consensus that have now emerged in Japan and in the international community, as follows.

To respond squarely to the changing needs and requirements of the people and governments of partner countries as well as to the changing global issues affecting the lives of all people around the world, Japan in collaboration with both OECD/DAC donors and emerging donors, as well as with partner countries, will continue among others:

a) to try its best to increase its ODA;

b) to enhance the quality of its IDA by stressing the Ownership of partner countries, enhancing the human and institutional capacity of partner countries to deal with both domestic and external shocks and changes affecting their national development;

c) to decentralize decision authority over ODA implementation to local representative offices of Japan and enhance their capacity to work with the government and local community stakeholders and other bilateral and multilateral donors in partner countries;

d) to improve the system of ODA evaluation in Japan and assist partner countries to improve their evaluation systems in favour of the outcome- and evidence-based system, assist the development of evaluation professionals and experts in partner 
countries and feedback its findings to policy makers and civil society groups;

e) to participate effectively in the discussion and negotiation in the United Nations and at other forum to reach an international consensus on post-ESD Plan of Action in 2014 and post-MDG Plan of Action in 2015 and on Climate Change Plan of Action by 2015 to start a new regime on Climate Change in 2020.

f) to give bilateral ODA priority to poverty reduction, education, health, environment, human rights and good governance in partner countries;

g) to expand its ODA through local governments and communities as well as to local NGOs engaged in the above priority areas of Japan's ODA;

h) to promote public-private partnerships including finance for the development of infrastructures and productive sectors such as agriculture, minining, manufacturing and tourism and so on;

i) to strengthen policy coherence, coordination and collaboration in partner countries between international trade, investment and ODA;

j) to increase its ODA in favour of least developed, low-income and small developing island countries:

k) to enhance the capacity of partner countries to promote conflict prevention and resolution and peace bilding;

1) to persuade partner countries to apply the Principle of Respective Capabilities endorsed at the COP 17 in Johannesburg, South Africa to all effort to provide global issues.

It is reassuring to learn that people and governments of all the partner countries will also continue to review their own national development policies and implementation machinery, including those related to ODA, to respond jointly with the donor community to the global challenges facing us all in the coming decades of the $21^{\text {st }}$ century. It is our earnest hope that the day when every country will be able to stand on its own feet and will not require any ODA from bilateral and multilateral donor community will not be too far away, possibly before the end of this century, and that in the meantime. all countries, developing and developed, will continue to help each other under emergency and whenever deemed necessary. 


\section{References}

1) $\mathrm{ADHOC}$ and ADP, eds., Report of the Workshop on Democratic Governance in Cambodia, November, 2004;

2) AIHR and ADP, eds., Report of the Workshop on Democracy and Good Governance in Thailand, March, 2006;

3) Association for the Promotion of International Cooperation (APIC), 2009, Kokusai Kyoryoku ni kansuru Chosa Hokokusho (A Report on International Cooperation), Tokyo: APIC, 2009..

4) Asahi Newspaper, Morning Edition for Tokyo, 1 November, 2013, p. 34;

5) Government of Japan, Ministry of Foreign Affairs (MOFA), White Paper on Japan's Official Development Assistance (ODA), relevant years;

6) , MOFA, 1992, ODA Charter;

7) , MOFA, 2003, Revised ODA Charter;

8) , MOFA, 2006, Kaigai Keizai Kyoryoku no Arikata ni tsuite (In Search of Japan's Overseas Economic Cooperation Tomorrow).

9) , MOFA, Japan's Annual ODA Evaluation Report, relevant years;

10) Ministry of International Trade and Industry (MITI, now, renamed Ministry of Economy, Trade and Industry or METI), White Paper on Economic Cooperation, relevant years;

11) Hirono, Ryokichi, 2001, Japan's ODA in the Global Economy: Contributions and Challenges, JICA/JOCV, Komagane Training Centre, January, 2001;

12) , 2001, "Japanese Assistance for Human Resources Development in ASEAN Countries in Thailand Human Resources Foundation, Report of the Conference on Human Resources Development in ASEAN, held in Bangkok in March, 2001

13) , 2001, "Waga Kuni ODA Seisaku no Tenkai: Hanseiki no Sogo Hyoka Shiron (Japan's ODA Policy during the Last Half a Century: An Overall Evaluation), Toshi Mondai Kenkyu (Studies on Urban Problems), October, 2001.

14) 2003, "Reorienting International Development to Accelerate Poverty Reduction and Ensure Sustainability as the Century's Top Development Goals," International Review for Environmental Strategies, vol.4, No.1, Summer 2003;

15) , ed., 2004, Enhancing Democratic Governance in East Asia: Empowering People and Institutions for Building Sustainable Society, May, 2004 
16) 2005, "Promoting Sustainable Development through Education in the Era of Globalization: A Japanese Perspective," Proceedings of the Conference on the International Launch in Higher Education, Committing Universities to Sustainable Development, April 2005, Graz, Austria, pp.14-21;

17) 2005, "Nihon no Gaiko Seisaku to ODA: Haneiki no Keiken kara Shorai eno Tenbo (Japan's Foreign Policy and ODA: its Reflections on the basis of the Last Half a Century and Looking Ahead into the Future)" in Kokusai Mondai (International Affairs), No. 548, November, 2005;

18) 2012, "Reflections and Moving Forward in Results-based Policy Review and Budgeting: Case of Japan," presented at the Malaysian Evaluation Society's (MES) 5th International Evaluation Conference 2012 held in Kuala Lumpur on 10-14 September, 2012;

19) 2013, "A Long Unfinished Journey for Effective Evaluation: Lessons from Japan and Asia," presented at the Sri Lanka Evaluation Society's (SLEVA) International Conference at Mount Lavinia Hotel, Sri Lanka on 23-25 July, 2013.

20) Inada, Junichi, 1997, "Democracy and Stability: Political Considerations in Japan's ODA to Myanmar and China," in T. Matsumae and L. C. Chen, eds., In Pursuit of Common Values in Asia: Japan's ODA Charter Re-evaluated, Tokai University Press, 1997;

21) JICA, 1999, 21 Seiki no JICA no Aritakata nit suite (In Search for a new JICA in the 21st Century), Tokyo: JICA, 1999.

22) Keizai Doyukai (Japan Association of Corporate Executives) and Committee for Economic Development (CED). eds., 1971, Development Assistance to Southeast Asia, Tokyo: KD and Washington, D.C: CED, 1971,

23) Minato, Naonobu and Nobuko Fujita, eds., 2009, Evaluating Development Assistance: A Japanese Perspective, Tokyo: Foundation for Advanced Studies on International Development 'FASID), 2009;

24) MNWNGO and ADP, eds., Report on Democratic Governance and Civil Society Participation in Mongolia, November, 2004,

25) Nakajima, Akira, 1997, “Japan's ODA: Present Performance and Tasks Ahead," in Tatsuro Matumae abd Lincoln C. Chen, eds., In Pursuit of Common Values in Asia: Japan's ODA Charter Re-evaluated, Tokai University Press, 1997;

26) OECD/DAC, Development Cooperation Report, relevant years;

27) UNDP, Human Development Report, relevant years;

28) United Nations, 2004 World Summit Outcome, A/60/L.1, New York.

29) World Bank, World Development Report, relevant years. 